IZA DP No. 8989

Is There a Link Between Employer-Provided Health Insurance and Job Mobility?

Evidence from Recent Micro Data

Benjamin W. Chute

Phanindra V. Wunnava

April 2015 


\title{
Is There a Link Between Employer-Provided Health Insurance and Job Mobility? Evidence from Recent Micro Data
}

\author{
Benjamin W. Chute \\ Accenture \\ and Middlebury College \\ Phanindra V. Wunnava \\ Middlebury College \\ and IZA
}

Discussion Paper No. 8989

April 2015

IZA

P.O. Box 7240

53072 Bonn

Germany

Phone: +49-228-3894-0

Fax: +49-228-3894-180

E-mail: iza@iza.org

Any opinions expressed here are those of the author(s) and not those of IZA. Research published in this series may include views on policy, but the institute itself takes no institutional policy positions. The IZA research network is committed to the IZA Guiding Principles of Research Integrity.

The Institute for the Study of Labor (IZA) in Bonn is a local and virtual international research center and a place of communication between science, politics and business. IZA is an independent nonprofit organization supported by Deutsche Post Foundation. The center is associated with the University of Bonn and offers a stimulating research environment through its international network, workshops and conferences, data service, project support, research visits and doctoral program. IZA engages in (i) original and internationally competitive research in all fields of labor economics, (ii) development of policy concepts, and (iii) dissemination of research results and concepts to the interested public.

IZA Discussion Papers often represent preliminary work and are circulated to encourage discussion. Citation of such a paper should account for its provisional character. A revised version may be available directly from the author. 


\section{ABSTRACT}

\section{Is There a Link Between Employer-Provided Health Insurance and Job Mobility? Evidence from Recent Micro Data*}

This study investigates the prevalence and severity of job immobility induced by the provision of employer-sponsored health insurance - a phenomenon known as 'job-lock'. Using data from the National Longitudinal Survey of Youth from 1994 to 2010, job-lock is identified by measuring the impact of employer-sponsored health insurance on voluntary job turnover frequency. Estimates from a logistic regression with random effects indicate that job-lock reduces voluntary job turnover by $20 \%$ per year. These results that are consistent with past research and are also supported by two alternative identification strategies employed in this paper. Our results indicate a persistence of the job-lock effect, despite two major policy interventions designed to mitigate it (COBRA and HIPAA) and signal a fundamental misunderstanding of its causes. Both policies made health insurance more portable between employers, but this paper presents evidence from a quasi-natural experiment to suggest that the problem is a lack of viable alternative private sources of health insurance. In this model, we find evidence that access to health insurance through one's spouse or partner dramatically increases voluntary job turnover. This finding has significant bearing on predicted impacts of the Patient Protection and Affordable Care Act (2010) and the individual health insurance exchanges catalyzed by it; these new markets will create risk pools that may 'unlock' a job-locked individual by providing them a viable alternative to employersponsored health insurance.

JEL Classification: $\quad$ I13, J16, J32, J51

Keywords: $\quad$ job-lock, COBRA (1985), HIPAA (1996), Affordable Care Act (2010), random effects, difference-in-difference, voluntary job switch

Corresponding author:

Phanindra V. Wunnava

Middlebury College

Warner Hall 502F

Middlebury, VT 05753

USA

E-mail:wunnava@middlebury.edu

\footnotetext{
* Earlier drafts of this paper were presented at the Western Economic Association International Conference session titled: 'Health Economics and Work Injury Session' [Denver, CO in June 2014], and at the ASSA Meetings for a LERA Papers session: 'Micro and Macro Effects of EmployerProvided Job Benefits' [Boston, MA in January 2015]. We would like to thank the participants of this panel for their insights. We also like to thank James Bang, Jessica Holmes for their suggestions, Brenda Ellis for her editorial recommendations, and Sherif Nada for his technical assistance.
} 


\section{INTRODUCTION}

The United States healthcare system may be discouraging millions of employees from voluntarily changing their jobs. This paper contributes to the mounting evidence of substantial 'job-lock' - a term used to describe the job immobility induced by the system of employer-sponsored health insurance that covers more than half of Americans.

The United States labor market is particularly susceptible to labor market distortions rooted in linkages to healthcare because individuals are more exposed to the high and increasing cost of healthcare than their peers in other OECD countries. Per capita spending on healthcare in the United States was \$8,508 in 2011 - the highest in the world (OECD Health Data, 2013). This accounted for 17.7\% of GDP in 2011 and, if current trends continue, is projected to rise to 19.6\% of GDP in 2021 (OECD Health Data, 2013) (Commonwealth Fund, 2013). Further compounding the impact of these costs on the private individual, public coverage of healthcare expenditures in the United States is the lowest of all OECD countries (OECD Health Data, 2013); In 2012, only 32.6\% of Americans were enrolled in public health insurance plans such as Medicare, Medicaid, and State Children's Health Insurance Program (US Census Bureau, 2011). US public programs covered only $47.8 \%$ of healthcare spending in 2011 — far less than the non-US OECD average of 75.3\% (OECD Health Data, 2013).

\section{-Dangerous Linkage between Labor and Healthcare Markets}

For the two-thirds of US residents left uninsured by public programs, private insurance is primarily acquired through employers. The private market for health insurance is dominated by employersponsored insurance; in 2011, 68.2\% of Americans aged 18-64 were covered by employer-sponsored health insurance (US Census Bureau, 2013). This near-exclusive reliance upon employers to pool risk for non-public insurance links labor markets to the grim state of healthcare in the United States and creates the conditions necessary for 'job-locking' employees.

\section{-Determinants of Job-Lock}

Employees might become 'job-locked' for any number of reasons. Early literature speculated that joblock arises from the non-portability of health insurance between employers (Madrian, 1994; Bansak and Rafael, 2008; Okunade and Wunnava, 2002). Before two major policy interventions, switching jobs away from one sponsoring health insurance often meant a period of being either uncovered or else forced to buy substantially more expensive individual insurance. Furthermore, new plans might not cover pre-existing conditions and instituted probationary periods of months to years before fully covering employees. For fear of these outcomes, job-locked employees remain in a job even if they might be more productive (or happier) elsewhere. Reduced quality of employer-employee matching impacts not only the individual but also society at large. Lost productivity negatively impacts the entire economy by reducing output, wages, consumption, investment and other important economic drivers.

\section{-Policy: Past, Present and Future}

Recognizing the importance of limiting these labor market distortions, two major policy interventions COBRA (Consolidated Omnibus and Reconciliation Act of 1985) and HIPAA (Health Insurance Portability and Affordability Act of 1996) - aimed to alleviate job-lock by allowing individuals to extend their employer-sponsored coverage after termination of employment. Research has borne little evidence that these policies reduced job-lock substantially. Recent healthcare reform has the potential to reduce job-lock by different means. Major provisions of the Affordable Care Act (2010) intend to reduce job-lock not by extending employer-coverage, but rather by providing an alternative source for risk 
pooling through individual health insurance exchanges. Identifying the true drivers of job-lock is crucial to understanding how COBRA and HIPAA fell short of eradicating job-lock, predicting whether ACA will be more effective, and guiding future healthcare policy decisions.

\section{BACKGROUND}

Job-lock poses several significant identification problems-first, that provision of employer-sponsored health insurance is almost certainly correlated with unobserved positive job characteristics and second, that individual turnover propensities might be heterogeneous. The two primary strategies to overcome these problems are to either estimate increasingly accurate structural models (Gilleskie and Lutz, 2002) or exploit quasi-natural experiments that yield a reduced form of the problem and control for unobserved positive job characteristics that potentially reduce mobility (Gruber and Madrian, 2002).

Difference-in-difference methodology is the most commonly used methodology used to identify joblock. Researchers have utilized a variety of factors to attempt to sort individuals into treatment and control groups for these tests. Key methodologies include:

- Alternate sources of health insurance other than the employee's current employer (Cooper and Monheit, 1993; Madrian, 1994b; Gruber and Madrian, 1994)

- Family size - presuming a positive correlation between family size and healthcare costs) (Madrian, 1994; Kapur, 1998)

- Health conditions (Cooper and Monheit, 1993; Madrian 1994b; Kapur 1998; Berger, Black and Scott, 2004)

- Health status (Berger, Black and Scott, 2004)

Several papers have diverged from the literature standard of estimation using difference-in-difference estimation. Rather than use the typical binary variable indicating whether-or-not an individual switches jobs, Okunade and Wunnava (2002) made a novel contribution to the literature by estimating the magnitude of job lock through a worker's tenure at their primary job. The authors estimate that workers who are offered health insurance by their employers are likely to remain with their employer roughly one year longer than workers who were not offered insurance. One significant problem with this methodology is that it does not discriminate between voluntary and involuntary job switches.

Gilleskie and Lutz (2002) found smaller estimates of job-lock by using a model that attempts to correct for heterogeneity in the propensity for individuals to change jobs and how that influences sorting into jobs with and without employer-sponsored health insurance. Interestingly, they found no job-lock effect in married males and a small effect (10-15\% reduction in voluntary job-turnover rate) for unmarried males.

In their meta-analysis of 18 papers on the subject, Gruber and Madrian (2002) found that about onethird of papers find significant impacts of employer-sponsored insurance on employee job choices. Another third found no significant relationship, and the final third finds results that are highly contingent upon the specification of the model. Even though the data and methodology of the papers confirming the existence of job-lock differ substantially, their estimates of the magnitude of job lock are similar ranging from 25\%-50\% (Gruber and Madrian, 2002). 


\section{METHODOLOGY and EMPIRICS}

Research about the job lock phenomenon has yet to exploit recent increases in the quality and scope of data in the National Longitudinal Survey of Youth '79 (NLSY79). Recent rounds of surveys include a number of variables that can be leveraged to allay many of the concerns about benefits being correlated with unobserved positive job characteristics. After 1993, NLSY79 began administering an "Employer Supplement” which contains detailed job characteristics for up to five employers for each respondent including increasingly precise information about utilization of employee benefits (especially employersponsored health insurance). These employers are uniquely identifiable and can be matched across rounds with various job characteristics and outcomes (i.e. whether the respondent voluntarily switches jobs). Consequently, much stands to be gained from replication of past studies with improved model specifications, many more years of data and separate estimation by gender to account for heterogeneity. We also make a novel contribution to the literature by imputing a uniquely precise variable indicating a voluntary job switch from a question asking respondents why they left their past job. This allows job mobility decisions to be linked to rich individual and employer data, enabling estimation of a logistic model with random effects using a panel data framework.

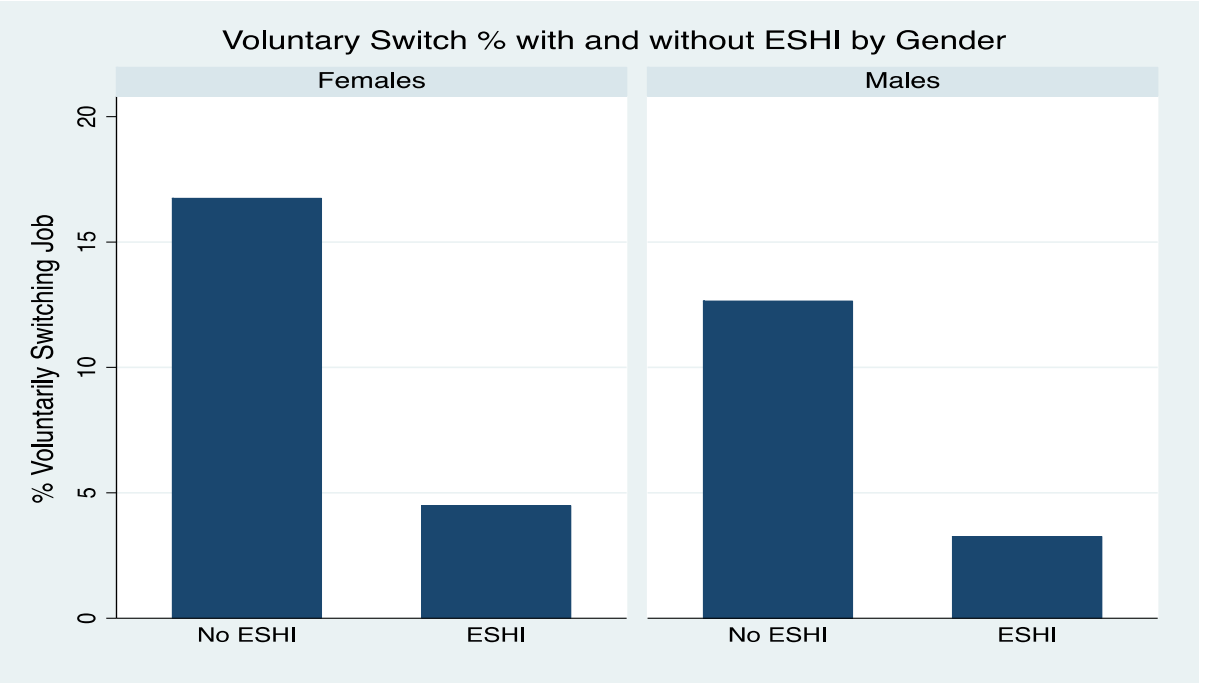

The National Longitudinal Survey of Youth of 1979 (NLSY79) surveyed 12,686 individuals from 1979 until 2010. The respondents were born between 1957 and 1964 at the beginning of the study and were interviewed annually until 1994 and biennially after 1994. NLSY79 contains information about labor market behavior, educational experiences, family background, aptitude tests, high school transcripts, government program participation, family life, health, assets and income. This study's dataset includes nine cross sections of NLSY79 recorded biennially from 1994 until 2010. The sample is a semibalanced panel of 43,556 observations spanning

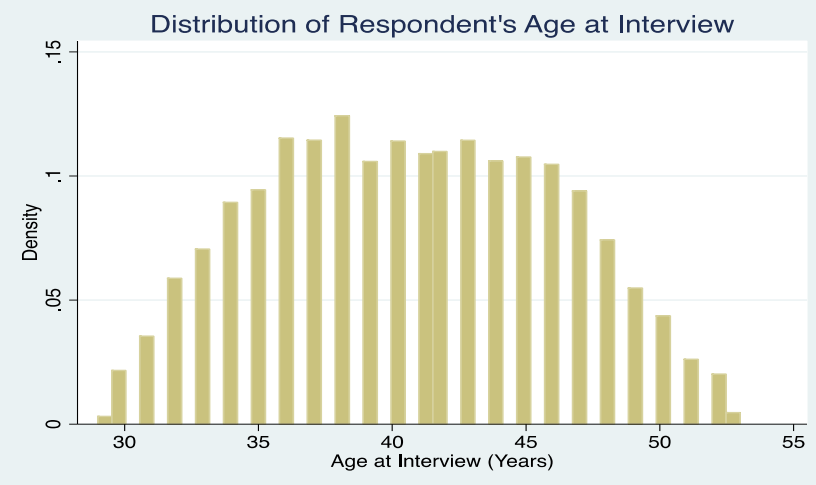
18 years limited to respondents who are in the labor force and had valid answers to key variables. Those 18 years span economic booms and busts, three presidencies (two Democratic and one Republican) and one major policy intervention intended to prevent job-lock (HIPAA). 
One criticism of NLSY79 data used to be that the respondents were too young, but the respondents now range from age 29 to 53 and their ages are approximately normally distributed around a mean of 40.69 years. The NLSY79 respondents in our sample in the stage of life where we would expect job-lock to be most strong - during family formation, when the respondents become responsible for the healthcare costs of more than themselves. Furthermore, the majority of the respondents are likely to be past their physical prime and anticipate increasing personal healthcare expenditures.

The data describe each respondent's compensation package, composed of an imputed hourly rate of pay and benefits including health insurance, life insurance, maternity/paternity leave and retirement planning. Hourly rate of pay should be highly deterministic of whether or not an individual voluntarily switches jobs because a higher rate of pay not only makes a current job look more attractive, it also makes the alternatives to which one would switch look less attractive. The mean hourly rate of pay in the dataset is $\$ 17.59811$ and the median is $\$ 14$.

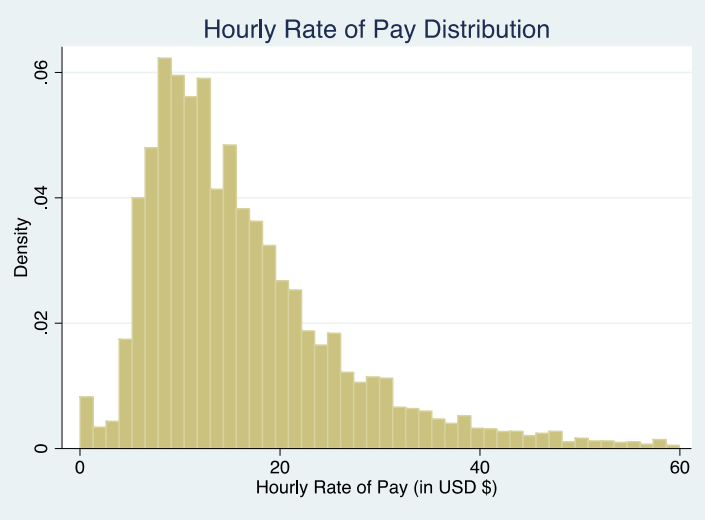

The benefits package is another important component of employee compensation. In the sample, $80.9 \%$ of respondents in the sample were offered health insurance by their primary employers. $71.1 \%$ were offered life insurance, $70.9 \%$ were offered guaranteed maternity/paternity leave and $71.8 \%$ were offered a form of assisted retirement planning such as a 401(k) or pension. Other benefits, especially retirement planning, are generally regarded as more portable than health insurance, so we would expect them to be less-likely to job-lock an employee than health insurance. These benefits do, however, exhibit many of the characteristics of job-lock inducing benefits including asymmetric valuation of benefits by employees, imperfect information on behalf of firms, general inability of the firm to adjust terms of the benefit to the marginal employee, and asymmetric cost to firms to provide these benefits. For this reason we expect to find a negative effect on job turnover from employee benefits.

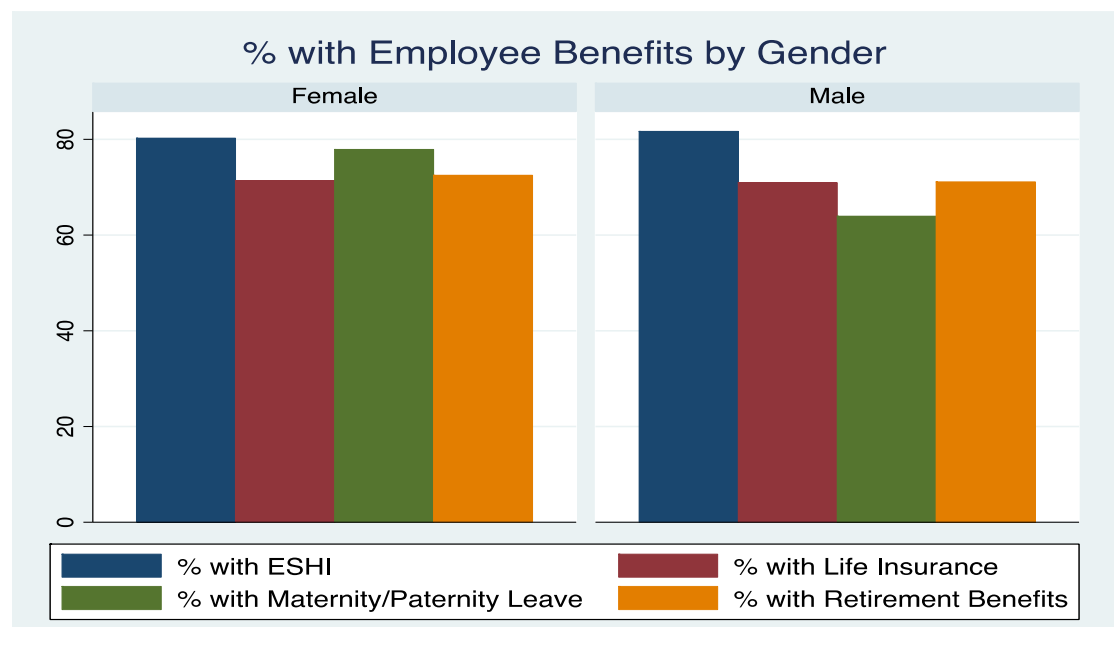


The almost-certain correlation between provision of employee benefits and other unobserved positive job characteristics causes significant job-lock identification issues because they are correlated to provision of employer-sponsored health insurance and likely reduce the propensity to switch away from a "good" job. Observe how wages for those without EPHI are clustered just below $\$ 10$ an hour, while jobs with EPHI skew much further right.

Many of these positive job characteristics can be accounted for with employer-specific information documented in the "Employer Supplement" of the NLSY79 since 1994. Union

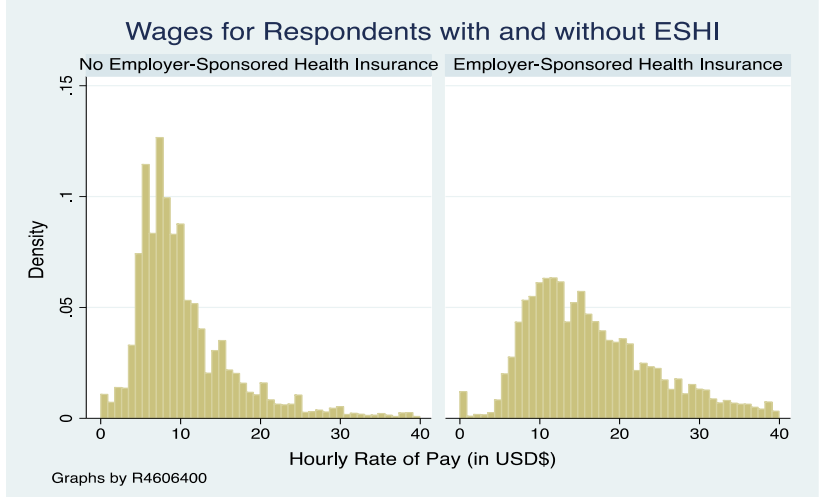
status, for example, is highly correlated with a whole host of benefits and on-the-job amenities. Past research (Okunade and Wunnava, 2002) has found union status to be robustly correlated with lower job turnover and longer on-the-job tenure.

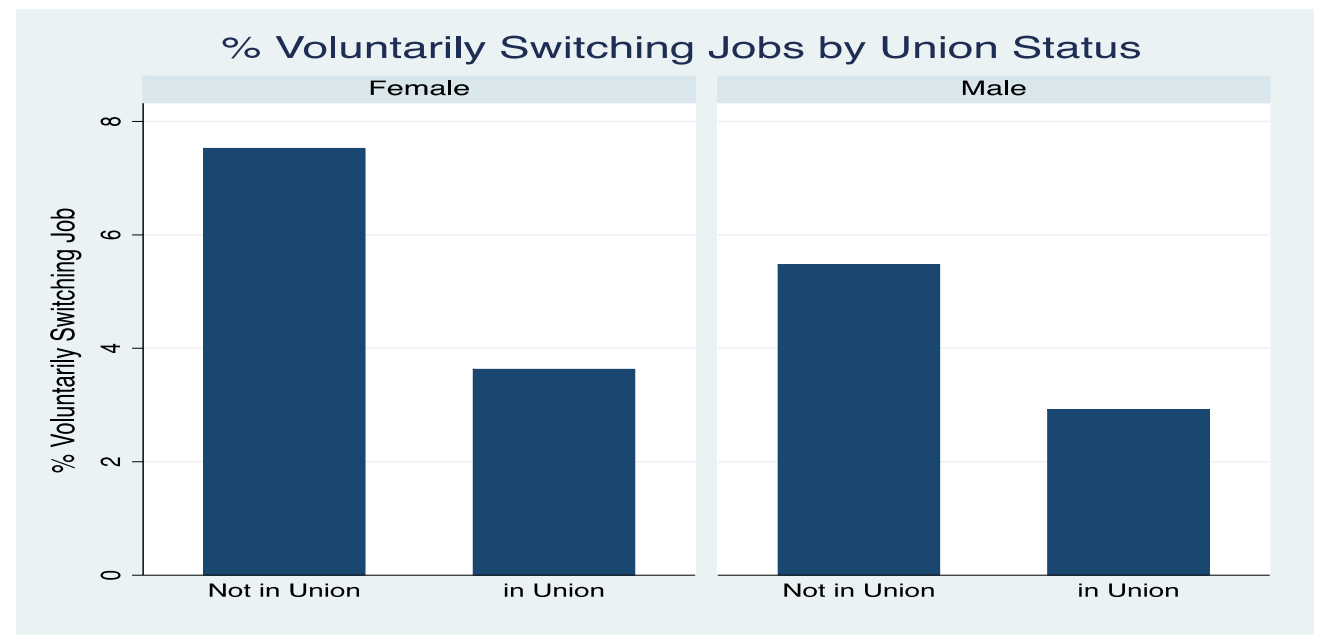

3-digit 1970 census codes for industry and occupation further improve the model specification and reduce bias from the "good jobs" effect. We group these into twelve industry groups for agriculture, mining, construction, manufacturing, transportation, retail, finance, business, personal service, entertainment, professional service and public administration. Respondents are also grouped into eleven occupation groups: professionals, managers, salesmen, clerical workers, craftsmen, military, operatives, laborers, farm laborers, service workers and household workers. Accounting for these industry and occupation codes provides less-biased estimates of job-lock by accounting for unobserved, positive job characteristics.

In addition to compensation, benefits, industry, occupation and union status, the size of a firm could also impact job mobility decisions.. Large firms, which are much more likely to provide employersponsored health insurance than their smaller peers, also have "internal labor markets" that offer more opportunity for career/job changes within that firm (Robinson and Wunnava 1991). Omitting firm size, then, would negatively bias the effect of EPHI on voluntary job switches and cause us to overestimate the effect of job-lock. 


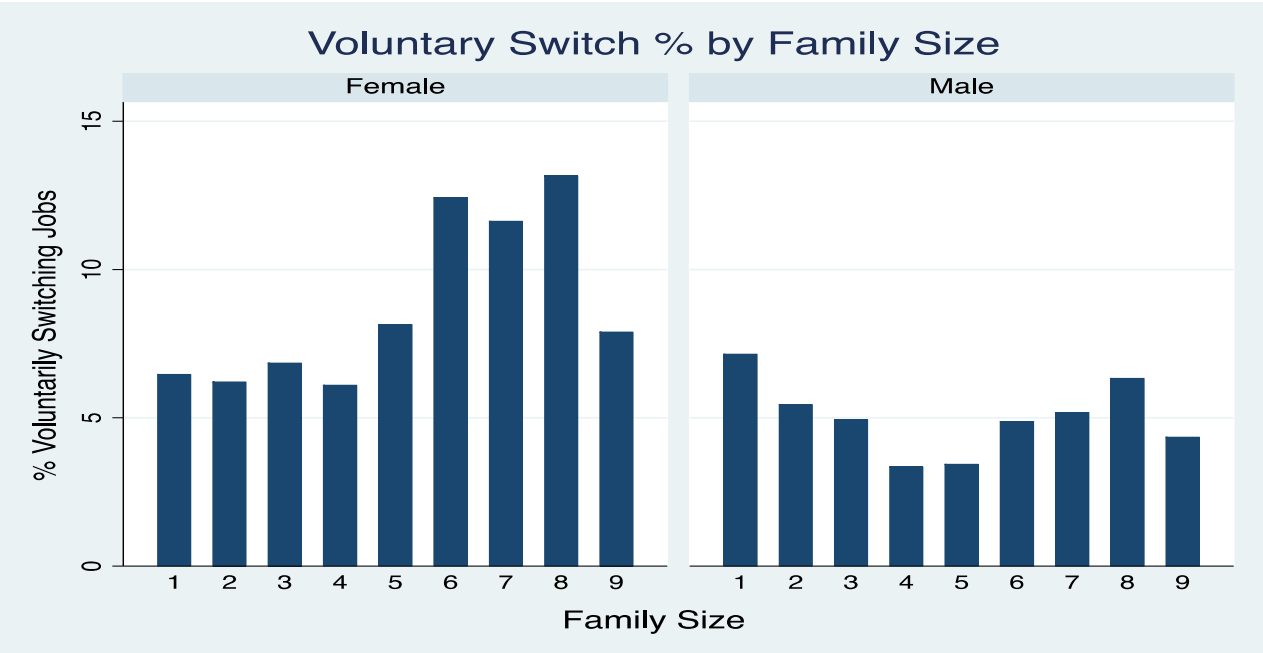

Individual heterogeneity may also affect job exit decisions via expected medical expenses and valuation of benefits. The large sample size enables estimating each model separately by gender in order to account for heterogeneity in the effects of various personal characteristics on job-lock, particularly family size. Though male propensity to voluntarily switch jobs is not substantially influenced by family size, females are much more likely to voluntarily switch jobs as their family size increases. Age at interview is specified by a linear and squared term in order to accommodate a non-linear effect of age on turnover propensity. Allowing this flexibility in the model accounts for changes throughout the lifecycle, especially as respondents settle into careers and families later in life. Further information about key variables may be found below in the tables below, entitled 'Descriptive Statistics'. Because this paper estimates most models disaggregated by gender, descriptive statistics are also disaggregated by gender. For information about how 'Voluntary Job Switch' is imputed, refer to Appendix B. For more detail about the definition of each variable, please refer to Appendix D.

\begin{tabular}{|c|c|c|c|c|c|c|c|c|c|c|c|}
\hline \multirow[b]{2}{*}{ Variable } & \multicolumn{3}{|c|}{$\begin{array}{c}\text { Descriptive Statistics } \\
\text { Females }\end{array}$} & \multirow[b]{2}{*}{ Min } & \multirow[b]{2}{*}{ Max } & \multicolumn{6}{|c|}{$\begin{array}{c}\text { Descriptive Statistics } \\
\text { Males }\end{array}$} \\
\hline & Obs & Mean & Std. Dev. & & & Variable & Obs & Mean & Std. Dev. & Min & Max \\
\hline R_ESHI & 21780 & 0.8022957 & 0.398277 & 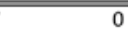 & 1 & R_ESHI & 21776 & 0.816633 & 0.386976 & $\overline{0} 0$ & 1 \\
\hline Voluntary_Switch & 21780 & 0.0691001 & 0.2536301 & 0 & 1 & Voluntary_Switch & 21776 & 0.0498255 & 0.2175893 & 0 & 1 \\
\hline Tenure & 21780 & 362.2418 & 342.8039 & 1 & 1969 & Tenure & 21776 & 381.9006 & 357.9208 & 1 & 1763 \\
\hline life_j1 & 21780 & 0.7138659 & 0.4519632 & 0 & & life j1 & 21776 & 0.7094508 & 0.4540263 & 0 & 1 \\
\hline mat_pat_j1 & 21780 & 0.7790174 & 0.4149183 & 0 & 1 & mat_pat_j1 & 21776 & 0.6393736 & 0.4801933 & 0 & 1 \\
\hline retire j1 & 21780 & 0.7247475 & 0.4466517 & 0 & 1 & retire $\mathrm{j} 1$ & 21776 & 0.7112877 & 0.4531743 & 0 & 1 \\
\hline union & 21780 & 0.1580349 & 0.3647821 & 0 & 1 & union & 21776 & 0.1936076 & 0.395134 & 0 & 1 \\
\hline minority & 21780 & 0.494674 & 0.4999831 & 0 & 1 & minority & 21776 & 0.4795187 & 0.4995918 & 0 & 1 \\
\hline highest_grade & 21780 & 13.49197 & 2.362793 & 0 & 20 & highest_grade & 21776 & 13.19852 & 2.488705 & 3 & 20 \\
\hline ageatint & 21780 & 40.85624 & 5.353713 & 29 & 53 & ageatint & 21776 & 40.53449 & 5.404697 & 29 & 53 \\
\hline ageatint_2 & 21780 & 1697.894 & 439.1226 & 841 & 2809 & ageatint_2 & 21776 & 1672.254 & 441.6892 & 841 & 2809 \\
\hline married & 21780 & 0.5522498 & 0.4972739 & 0 & 1 & married & 21776 & 0.6019471 & 0.4895077 & 0 & 1 \\
\hline famsize & 21780 & 3.181726 & 1.473813 & 1 & 14 & famsize & 21776 & 3.040457 & 1.585314 & 1 & 12 \\
\hline northeast & 21780 & 0.1460055 & 0.3531198 & 0 & 1 & northeast & 21776 & 0.1531043 & 0.3600963 & 0 & 1 \\
\hline n_central & 21780 & 0.2369605 & 0.4252276 & 0 & 1 & n_central & 21776 & 0.2404941 & 0.4273934 & 0 & 1 \\
\hline south & 21780 & 0.43618 & 0.4959217 & 0 & 1 & south & 21776 & 0.407421 & 0.4913657 & 0 & 1 \\
\hline west & 21780 & 0.180854 & 0.384906 & 0 & & west & 21776 & 0.1989805 & 0.3992425 & 0 & 1 \\
\hline large_firm & 21780 & 0.1871901 & 0.390073 & 0 & 1 & large_firm & 21776 & 0.1834589 & 0.3870511 & 0 & 1 \\
\hline In_hrp1 & 21780 & 2.497188 & 0.7681183 & -4.60517 & 6.047538 & In_hrp1 & 21776 & 2.756864 & 0.7067566 & -4.60517 & 6.682196 \\
\hline daily_hrs_j1 & 21780 & 10.42998 & 8.69126 & 1 & 120 & daily_hrs_j1 & 21776 & 11.91954 & 10.65079 & 1 & 140 \\
\hline
\end{tabular}

Because identification of job-lock hinges on accounting for unobserved positive job characteristics and individual sorting into different jobs based on different turnover propensities (Gilleskie and Lutz 2002), any methodology involves making at least one critical assumption. In order to decrease reliance upon any single assumption, this paper investigates models job lock with three different strategies. The first strategy is a novel contribution to the literature and the others are loose replications of past studies performed as a robustness check. Two strategies attempt to model the decision to switch jobs as 
accurately as possible with recent micro data, and a third exploits a quasi-natural experiment. Each model makes critical assumptions, but they make different assumptions and therefore serve as a robustness check for each other test.

The main research question of "Does provision of employer-sponsored health insurance limit job mobility?” can be broken down into three smaller, more manageable research questions with their own identification strategies and estimation techniques:

1. Does employer-sponsored health insurance influence affect the probability of a voluntary job switch? [estimation strategy: Logistic model with random effects]: We impute a variable indicating a voluntary job switch and model how compensation, employer and individual characteristics influence the probability of a voluntary job switch by estimating a logistic model using random effects. Random effects assume that all individual characteristics are captured by the coefficient estimates, but because individuals were randomly selected to be in the sample, their differences are treated as random and not fixed ${ }^{1}$ (Hill, Griffiths and Lim 2011). Stated compactly, model (1):

$$
\ln \left(\frac{Y_{i j t}}{1-Y_{i j t}}\right)=\beta_{0}+\beta_{1} R_{-} E S H I_{i j t}+\mathrm{X} \Gamma+\Upsilon \Theta+\Omega \Phi+\varepsilon_{i}+v_{i t}
$$

Where $Y_{i j}$ is the probability that individual ' $\mathrm{i}$ ' will leave job ' $\mathrm{j}$ ' in time period ' $\mathrm{t}$ ', $\mathrm{X}$ is a vector of compensation benefits, $\mathrm{Y}$ is a vector of employer characteristics (including industry and occupation controls) and $\Omega$ is a vector of individual characteristics. Please refer to Table 1 [included in the text] for the empirical results for this estimation strategy.

2. Does employer-sponsored health insurance influence how long someone stays with an employer? [estimation strategy: Ordinary Least Squares (OLS)]: This follows the methodology of Okunade and Wunnava (2002) but uses much more recent data, a larger sample, and more precise specification. Stated compactly the model (2):

$$
Y_{i j t}=\beta_{0}+\beta_{1} R_{-} E S H I_{i j t}+\mathrm{X} \Gamma+\Upsilon \Theta+\Omega \Phi+\varepsilon_{i t}
$$

Where $\mathrm{Y}_{\mathrm{ij}}$ is the tenure of individual ' $\mathrm{i}$ ' at firm ' $\mathrm{j}$ ' at time ' $\mathrm{t}$ ' in number of weeks, $\mathrm{X}$ is a vector of compensation benefits, $\mathrm{Y}$ is a vector of employer characteristics (including industry and occupation controls) and $\Omega$ is a vector of individual characteristics. Please refer to Table 2 [included in Appendix A] for the empirical results for this estimation strategy.

3. Does availability of other, affordable health insurance affect tenure and voluntary job turnover? [estimation strategy: Difference-in-Difference]: In this strategy, provision of employer-sponsored health insurance from a spouse is leveraged as exogenous sorting into treatment and control groups. Difference in Difference testing can be used for the previously-described Logit and OLS models by adding two new variables. The first is ' $P \_E S H I$ ', a variable indicating whether or not the respondent has a spouse or partner whose current employer pays for any part of the respondents insurance. Interacting this term with

\footnotetext{
${ }^{1}$ Random effects are random error terms where we assume that error terms have zero mean, are uncorrelated across individuals and have constant variance: $E\left(u_{i}\right)=0, \operatorname{cov}\left(u_{i}, u_{j}\right)=0, i \neq j, \operatorname{var}\left(u_{i}\right)=\sigma_{u}^{2}$ (Hill, Griffiths and Lim 2011).
} 
the dummy variable indicating whether or not the respondent has employer-sponsored health insurance in the variable 'R_ESHI*P_ESHI' gives us the following model ( $3 a$ ):

$$
\ln \left(\frac{Y_{i j t}}{1-Y_{i j t}}\right)=\beta_{0}+\beta_{1} R_{-} E S H I_{i j t}+\beta_{2} P_{-} E S H I_{i j t}+\beta_{3}\left(R_{-} E S H I * P_{-} E S H I\right)_{i t}+X \Gamma+\gamma \Theta+\Omega \Phi+\varepsilon_{i}+v_{i t}
$$

Where $Y_{i j}$ is the probability that individual ' $\mathrm{i}$ ' will leave job ' $\mathrm{j}$ ' in time period ' $\mathrm{t}$ ', $\mathrm{X}$ is a vector of compensation benefits, $\gamma$ is a vector of employer characteristics (including industry and occupation codes) and $\Omega$ is a vector of individual characteristics. The Table A below helps visualize how difference-indifference estimation allows to capture job-lock.

Table A: Estimating Job-Lock with Difference-in-Difference Estimation

\begin{tabular}{|l|l|l|}
\hline & Partner/Spouse has no ESHI & Partner/Spouse has ESHI \\
\hline R has no ESHI & A (not job-locked) & B (not job-locked) \\
\hline R has ESHI & C (job-locked) & D (not job-locked) \\
\hline
\end{tabular}

Though the groups that are and are not offered ESHI may differ in substantially different ways, we treat the provision of ESHI from a spouse as an exogenous treatment effect that frees the group of respondents with ESHI from job-lock. Please refer to Table 3 [included in Appendix A] for the empirical results for this estimation strategy. Because of the limited availability about other forms of insurance before 2002, we restrict our sample to 2002-2010 for the difference-in-difference testing. The number of observations is cut to 10,354, but most sample means remain consistent with those described earlier. Further, note that the results are not separated by gender as in earlier estimation. This was done in order to preserve statistical power because of the extra degrees of freedom demanded by difference-in-difference estimation.

In the case of the Table 1, we would expect the coefficient on ' $R \_E S H{ }^{*} P \_E S H I$ ' to be positive because having an alternative source of insurance should make it easier for a respondent to voluntarily switch jobs. We expect this coefficient to reflect the majority magnitude of the job lock because it captures the effect of moving from group $\mathrm{C}$ to group $\mathrm{D}$, controlling for all other job and individual characteristics.

We also run a difference-in-difference test on the OLS specification of the model. The model follows a similar specification but the coefficient on the interaction term would be expected to be negative, since having other insurance would free the respondent to leave their job and then cause them to have a lower tenure at their primary job. This model $(3 b)$ :

$$
Y_{i j t}=\beta_{0}+\beta_{1} R_{-} E S H I_{i j t}+\beta_{2} P_{-} E S H I_{i j t}+\beta_{3}\left(R_{-} E S H I * P_{-} E S H I\right)_{i t}+X \Gamma+\Upsilon \Theta+\Omega \Phi+\varepsilon_{i t}
$$

Where $Y_{i j}$ is the tenure of individual ' $\mathrm{i}$ ' at job ' $\mathrm{j}$ ' in time period ' $\mathrm{t}$ ', $\mathrm{X}$ is a vector of compensation benefits, $\mathrm{Y}$ is a vector of employer characteristics (including industry and occupation codes) and $\Omega$ is a vector of individual characteristics. The relevant regression results of models 2 , 3a, and $3 \mathrm{~b}$ are presented in Appendix A. 
Employer-sponsored health insurance is positively correlated with measures of job-lock in all three empirical strategies. OLS estimates of model 2 [presented in Appendix A] predict that ESHI induces an employee to stay with their employer nearly a year longer than their peers. LOGIT estimates [presented in Table 1 for model 1] predict that ESHI lowers the voluntary turnover rate for females by 1.89 percentage points, equivalent to a $27 \%$ increase over the sample mean of $6.9 \%$ (though not for males). Furthermore, difference-in-difference estimates [presented in Appendix A for model 3a] predict that unlocking a joblocked individual increases his or her propensity to voluntarily change jobs by 5.38 percentage points, nearly a $100 \%$ increase over the sample mean of $5.6 \%$.

Regardless of the OLS specification, ESHI (the indicator of whether or not an individual has ESHI) coefficient estimates are positive (as expected) and statistically as well as economically significant. Controlling for individual characteristics, employer characteristics, compensation packages and industry and occupation codes, male employees with ESHI are estimated to remain at the same employer 40.11 weeks longer than their peers without ESHI. The estimated effect is even stronger for females, who are predicted to remain on their job for an additional 47.44 weeks if they have ESHI.

Logistic estimation results are somewhat consistent with these linear predictions of the effect of ESHI. Estimated marginal effects indicate a 1.89 percentage point reduction in voluntary job switches for females, equivalent to a $27 \%$ increase over the sample mean of $6.9 \%$. This finding is consistent with other predictions in the literature. The effect of ESHI in this logistic model loses statistical significance for men after accounting for individual and employer characteristics.

Difference-in-difference estimates provide strong evidence for the presence of job lock. The interaction term indicates that, for those who have ESHI, having another form of insurance increases voluntary job switches by 5.28 percentage points. Compared to the sample mean of $5.6 \%$ (see appendix C) this is equivalent to a $94 \%$ increase in voluntary job turnover. This is also reflected in the differencein-differencing on job tenure, where we see that becoming 'unlocked' reduces a respondent's predicted tenure by more than a year (70 weeks). 
Table 1: Logistic estimates with random effects [model 1]

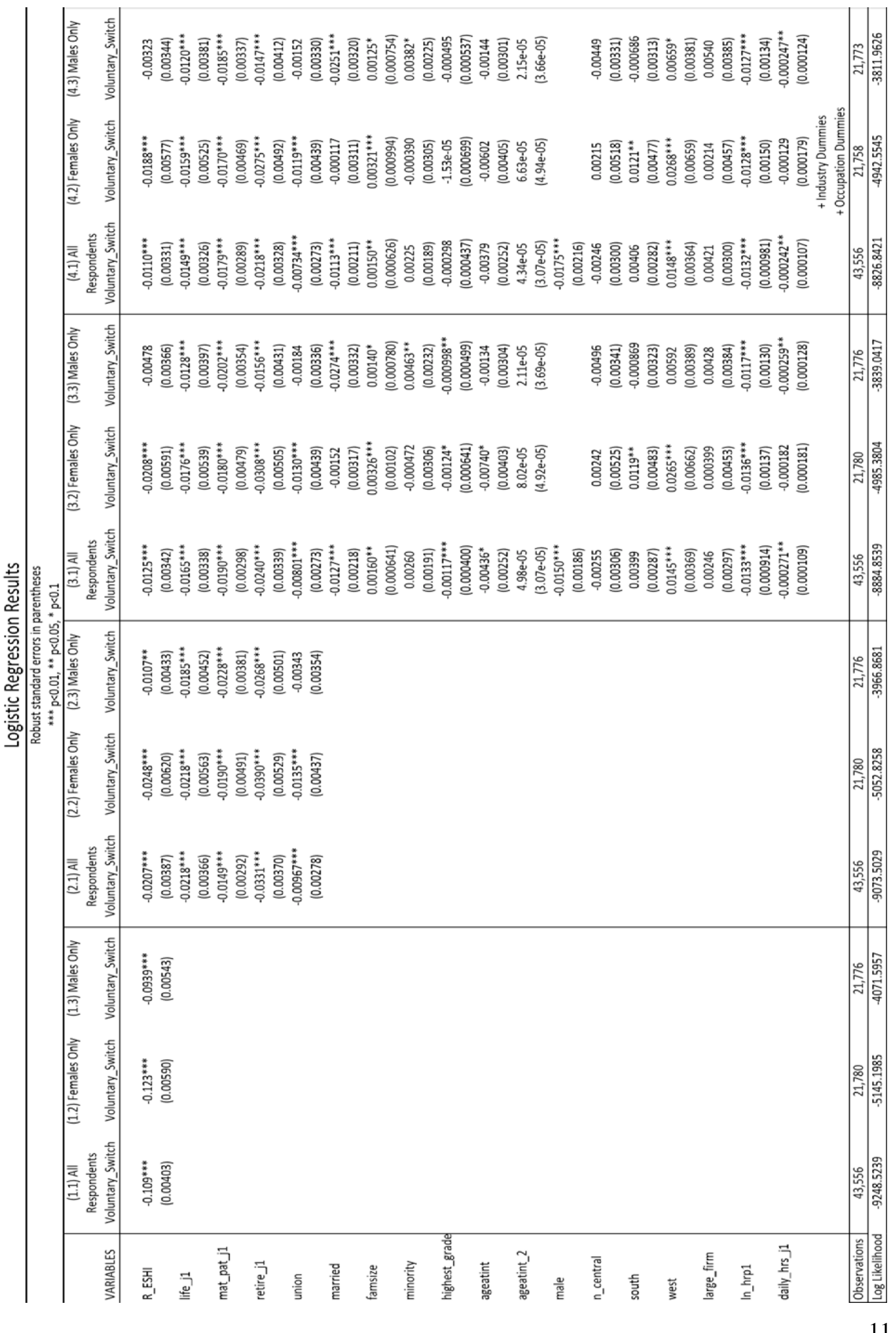


Other benefits also reduce the probability of a voluntary job switch, though the effect is not as strong as ESHI. Each is predicted to lower the voluntary job turnover rate by approximately $1 \%$. Guaranteed maternity and paternity leave have a persistent impact on lowering voluntary turnover rate and increasing job turnover throughout each model specification. Maternity and paternity leave seems to have the same effect on voluntary job turnover for males and females - a reduction of $1.3 \%$ — but it has a larger impact on the estimated tenure of females than males (increase of 40 weeks compared to an increase of 25 weeks). Estimates of the reduction in job turnover from retirement planning are somewhat surprising, since 401(k)s and other retirement savings vehicles are rather portable between employers. Retirement planning might then be treated as something similar to an increased wage, not an unreasonable proposition since it is essentially a delayed wage.

Union jobs seem to be exceptionally sticky. Across nearly all models and specifications, union jobs have a large and statistically significant effect on reducing job turnover. Workers with union jobs are estimated to remain in those jobs more than two years longer than their non-union counterparts. The effect on job turnover is strong for females, reducing voluntary switches by $20 \%$, but not statistically significantly for males.

Evidence for whether or not education has a positive impact on job mobility is mixed. Each marginal grade completed reduced predicted tenure on the job by several weeks, suggesting that the more educated might have more mobility. Once industry and occupation groups are accounted for in the second model (logistic), all statistical significance for the effect of education on the probability of a voluntary job switch disappears. Further, being married increases estimated job tenure for both males and females, but only impacts voluntary job turnover significantly for males, who experience a greater-than-30\% decrease in voluntary job turnover from being married. The effect of large firms on voluntary job switching and employer tenure is ambiguous. Estimates of its effect are positive and highly statistically significant for estimates of tenure at the primary job, but not for voluntary turnover. This may be due to the conflation of voluntary and involuntary job exits in our linear model. Perhaps workers are simply less likely to be fired in large firms than they are in small firms.

\section{CONCLUSION AND POLICY IMPLICATIONS}

Our results evidence both the systemic nature of job-lock and also a misunderstanding of its determinants. Two of the three identification strategies in this study loosely replicate the work of two previous studies — one published a decade ago, and another published exactly two decades ago — and find that 'job-lock' is as prevalent and severe today as it ever was. It is insightful to find that job-lock persists, even though the intervening years have brought policies meant to eradicate job-lock.

As previously mentioned, most literature on the topic of job-lock theorized that the non-portability of health insurance between employers caused job-lock. Accordingly, two major policy interventions a decade apart (COBRA and HIPAA) made health insurance more portable between employers. The fact that we find strong evidence of persistent job lock that is consistent with estimates made before HIPAA suggests that its continuation-of-coverage provisions were generally ineffective. It is not surprising that these policies were unsuccessful. The provisions of COBRA and HIPAA only help a small segment of those who are job-locked - those employees who are switching from one company offering ESHI to another company offering ESHI. Furthermore, these employees must make the switch within 18 months (before COBRA coverage expires) and be able to afford the substantial increase in healthcare costs necessitated by continuing coverage through COBRA (because the employee must pick up the employer's 
contribution as well). Those who would have switched to self-employment, a start-up, a smaller firm, begun their own business, or perhaps would have left the labor force to spend time with family would not have been unlocked from job-lock in any meaningful way by these policies.

This study provides evidence that facilitates reframing the causes of job-lock. Though healthcare portability appears not to have mitigated job-lock, the presence of an alternative form of health insurance doubles voluntary job turnover rate. Perhaps the cause of job-lock is the absence of other affordable and comprehensive sources for private health insurance. Any insurance product needs a pool in which to reduce risk, particularly risk due to adverse selection, but employers are effectively the exclusive source of non-public risk pooling in the United States (accounting for $90 \%$ of the private insurance market (Robert Wood Johnson Foundation, 2011)). Owing to adverse selection effects, those who choose to purchase individual insurance outside of these risk-pools face daunting health insurance costs.

The difference-in-difference results presented in this paper indicate what might happen to job mobility if there were to be a viable alternative source of health insurance and show positive signs for the fate of the Affordable Care Act, which aims to provide that alternative source. Future research ought to study the effect of the ACA on the job-lock effect, perhaps similar to the methodology of a natural experiment run in this paper.

Precisely measuring the welfare implications of job-lock is difficult, but we can go through a back-ofthe-envelope calculation. There are currently 144 million people in the labor force (Bureau of Labor Statistics, 2012). In our sample, 6\% of respondents voluntarily changed jobs every two years, so one may impute that the voluntary switch rate in the US economy is $3 \%$ annually. If job-lock reduces voluntary job turnover by $20 \%$ (a conservative estimate compared to other papers and our findings), that means that 864,000 people are discouraged from changing jobs annually. It is difficult to attach a value to each job switch, but a recent Forbes article (Forbes, 2013) says a decent rule of thumb is that job switchers generally gain a $10 \%$ bump in salary. There might be diminishing marginal returns to these switches, so let's assume a more conservative 5\% increase in salary over a median income of 45,000 USD annually (\$2250). This amounts to $\$ 1.944$ billion dollars in lost income annually and is perhaps only a small portion of the social price paid by society. Other social costs might result from lost household income for investment in child development, psychological costs from unhappy employees and parents, lower productivity and more. Further costs may come from reductions in self-employment and entrepreneurship - perhaps someone who would have started the new Google is too job-locked in her current large-firm job to leave!

Another worthwhile extension of job-lock research could be to investigate the impact of job-lock on investment in human capital. Some researchers have argued that job-lock might not be bad, since it incentivizes greater investment in non-firm-specific human capital (Kim and Philips 2010).

Job-lock might also substantially impact the bargaining positions of employers and employees in compensation negotiations - resulting in lower compensation for job-locked employees. Modeling the effects of job-lock through a principal agent model and examining the political economy of the effect would go a long ways in terms of estimating the welfare implications of job lock. This might be a key to understanding some of the increasing income inequality in the United States, particularly regarding the low end of the income spectrum. One might reasonably expect those lower on the income distribution to be more sensitive to income shocks and thus even more job-locked than those higher on the distribution. 
Job-lock might not only diminish their chances of switching to a better, higher-paying job, but also could reduce their wages at their current job via diminished bargaining power and wages. Better understanding of job-lock might just lead to better policies, healthier and wealthier citizens, and greater socioeconomic mobility leading to income equality among other things — that seems like a worthy timely pursuit.

\section{REFERENCES}

Bansak, Cynthia and Stephen Rafael. "The State Children's Health Insurance Program and Job Mobility: Identifying Job-Lock among Working Parents in Near-Poor Households." Industrial and Labor Relations Review 61, no 4 (July 2008): 564-579.

Berger, Mark C., Dan A. Black, and Frank A. Scott. "Is There Job Lock? Evidence from the PreHIPAA Era." Southern Economic Journal 70, no. 4 (April 2004): 953-976.

Carmen DeNavas-Walt, Bernadette D. Proctor, Jessica C. Smith. "Income, Poverty and Health Insurance Coverage in the United States: 2012." U.S. Census Bureau, September 2013.

Cooper, Philip F., and Alan C. Monheit. "Does Employment-Related Health Insurance Inhibit Job Mobility?" Inquiry 30, no. 4 (1993): 400-416.

Dafny, Leemore, Kate Ho, and Mauricio Varela. "Let Them Have Choice: Gains From Shifting Away from Employer-Sponsored Health Insurance and Toward an Individual Exchange." American Economic Journal: Economic Policy 5, no. 1 (Februar 2013): 32-58.

Gilleskie, Donna B. , and Byron F. Lutz. "The Impact of Employer-Provided Health Insurance on Dynamic Employment Transitions." The Journal of Human Resources 37, no. 1 (Winter 2002): 129-162.

Gruber, Jonathan, and Brigitte C. Madrian. "Health Insurance and Early RetirementL Evidence from the Availability of Continuation Coverage." Advances in the Economics of Aging (University of Chicago Press), 1996: 115-143.

Gruber, Jonathan, and Brigitte C. Madrian. "Health Insurance, Labor Supply, and Job Mobility: A Critical Review of the Literature." National Bureau of Economic Research, Inc, Working Papers: 8817, 2002.

Hill, R Carter, William F. Griffiths, and Guay C. Lim. Principles of Econometrics: Fourth Edition. John Wiley and Sons, 2011.

Hubert, Janicki. "Employment-Based Health Insurance: 2010." U.S. Census Bureau, February 2013.

Kapur, Kanika. "The Impact of Health on Job Mobility: A Measure of Job Lock." Industrial and Labor Relations Review 51, no. 2 (January 1998): 282-298.

Kim, Jaewhan , and Peter Philips. "Health Insurance and Worker Retention in the Construction Industy." Journal of Labor Research 30, no. 1 (March 2010): 20-38.

Madrian, Brigitte C. "Employment-Based Health Insurance and Job Mobility: Is There Evidence of Job-Lock?" Quarterly Journal of Economics 109, no. 1 (February 1994): 27-54. 
Madrian, Brigitte C. "The Effect of Health Insurance on Retirement." Brookings Papers on Economic Activity, no. 1 (1994): 181-232.

Monheit, Alan C., and Philip F. Cooper. "Health Insurance and Job Mobility: Theory and Evidence." Industrial and Labor Relations Review 48, no. 1 (October 1994): 65-85.

Okunade, Albert A., and Phanindra V. Wunnava. "Availability of Health Insurance and Gender Differences in 'Job-Lock': Evidence from NLSY." Journal of Forensic Economics 15, no. 2 (Spring-Summer 2002): 195-204.

Organization for Economic Co-Operation and Development (OECD). OECD Health Statistics -Frequently Requested Data. Paris, November 2013.

Robinson, Michael D, and Phanindra V. Wunnava . "Plant Size, Tenure and Discrimination in Internal Labor Markets." Economics Letters 36 (February 1991): 197-208.

Rosen, Sherwin. "The Theory of Equalizing Difference." Handbook of Labor Economics (Orley Ashenfelter and Richard Lanyard) 1 (1986): 641-692.

Sanz-de-Galdeano, Anna. "Job Lock and Public Policy: Clinton’s Second Mandate." Industrial and Labor Relations Review 59, no. 3 (April 2006): 430-437.

"State-Level Trends in Employer-Sponsored Health Insurance." Robert Wood Johnson Foundation and State Heath Access Data Assistance Center, June 2011.

Thomson, S, D Osborn, and M Jun. "International Profiles on Health Care Systems." (The Commonwealth Fund) 2013.

United States Census Bureau. "Income, Poverty, and Health Insurance Coverage in the United States." September 2011. 


\section{Appendix A: Additional Regression Results}

OLS Estimation Results (model 2: Inspired by Okunade and Wunnava 2002)

Robust standard errors in parentheses *** $p<0.01, * * p<0.05, * p<0.1$

\begin{tabular}{|c|c|c|c|c|c|c|}
\hline VARIABLES & $\begin{array}{c}\text { Females Only } \\
\text { Tenure } \\
\text { (Weeks at } \\
\text { Primary } \\
\text { Employer) }\end{array}$ & $\begin{array}{l}\text { Males Only } \\
\text { Tenure } \\
\text { (Weeks at } \\
\text { Primary } \\
\text { Employer) } \\
\end{array}$ & $\begin{array}{c}\text { Females Only } \\
\text { Tenure } \\
\text { (Weeks at } \\
\text { Primary } \\
\text { Employer) }\end{array}$ & $\begin{array}{l}\text { Males Only } \\
\text { Tenure (Weeks } \\
\text { at Primary } \\
\text { Employer) }\end{array}$ & $\begin{array}{c}\text { Females Only } \\
\begin{array}{c}\text { Tenure } \\
\text { (Weeks at } \\
\text { Primary } \\
\text { Employer) }\end{array}\end{array}$ & $\begin{array}{c}\text { Males Only } \\
\text { Tenure } \\
\text { (Weeks at } \\
\text { Primary } \\
\text { Employer) }\end{array}$ \\
\hline R_ESHI & $\begin{array}{c}59.44 * * * \\
(8.249)\end{array}$ & $\begin{array}{c}58.61 * * * \\
(8.554)\end{array}$ & $\begin{array}{c}51.19 * * * \\
(7.986)\end{array}$ & $\begin{array}{c}46.04 * * * \\
(8.092)\end{array}$ & $\begin{array}{c}47.44^{* * *} \\
(7.983)\end{array}$ & $\begin{array}{c}40.11 * * * \\
(7.941)\end{array}$ \\
\hline life ¡11 & $\begin{array}{c}37.50 * * * \\
(7.489)\end{array}$ & $\begin{array}{c}30.96 * * * \\
(7.820)\end{array}$ & $\begin{array}{c}18.16 * * \\
(7.180)\end{array}$ & $\begin{array}{c}17.46 * * \\
(7.392)\end{array}$ & $\begin{array}{c}11.39 \\
(7.161)\end{array}$ & $\begin{array}{c}10.51 \\
(7.283)\end{array}$ \\
\hline mat_pat_j1 & $\begin{array}{c}39.60 * * * \\
(6.931)\end{array}$ & $\begin{array}{c}59.32^{* * *} \\
(6.089)\end{array}$ & $\begin{array}{c}40.34 * * * \\
(6.599)\end{array}$ & $\begin{array}{c}37.73^{* * *} \\
(5.751)\end{array}$ & $\begin{array}{c}40.09 * * * \\
(6.545)\end{array}$ & $\begin{array}{c}25.37^{* * *} \\
(5.663)\end{array}$ \\
\hline retire_j1 & $\begin{array}{c}111.7 * * * \\
(6.595)\end{array}$ & $\begin{array}{c}73.48 * * * \\
(7.314)\end{array}$ & $\begin{array}{c}73.37 * * * \\
(6.386)\end{array}$ & $\begin{array}{c}37.26 * * * \\
(7.036)\end{array}$ & $\begin{array}{c}64.09 * * * \\
(6.395)\end{array}$ & $\begin{array}{c}32.48^{* * *} \\
(6.882)\end{array}$ \\
\hline union & $\begin{array}{c}126.8^{* * *} \\
(6.717)\end{array}$ & $\begin{array}{c}133.3^{* * *} \\
(6.485)\end{array}$ & $\begin{array}{c}127.2^{* * *} \\
(6.506)\end{array}$ & $\begin{array}{c}120.7^{* * *} \\
(6.150)\end{array}$ & $\begin{array}{c}119.5^{* * *} \\
(6.699)\end{array}$ & $\begin{array}{c}122.5^{* * *} \\
(6.372)\end{array}$ \\
\hline minority & & & $\begin{array}{c}2.798 \\
(4.590)\end{array}$ & $\begin{array}{c}-40.82 * * * \\
(4.674)\end{array}$ & $\begin{array}{c}4.310 \\
(4.589)\end{array}$ & $\begin{array}{c}-37.97 * * * \\
(4.616)\end{array}$ \\
\hline highest_grade & & & $\begin{array}{c}-1.597 * \\
(0.965)\end{array}$ & $\begin{array}{c}-12.24 * * * \\
(0.941)\end{array}$ & $\begin{array}{c}-4.304 * * * \\
(1.038)\end{array}$ & $\begin{array}{c}-15.27 * * * \\
(1.096)\end{array}$ \\
\hline ageatint & & & $\begin{array}{l}-8.021 \\
(6.095)\end{array}$ & $\begin{array}{l}-0.200 \\
(6.413)\end{array}$ & $\begin{array}{l}-10.02 \\
(6.235)\end{array}$ & $\begin{array}{c}3.215 \\
(6.511)\end{array}$ \\
\hline ageatint_2 & & & $\begin{array}{c}0.271^{* * *} \\
(0.0756)\end{array}$ & $\begin{array}{l}0.200 * * \\
(0.0801)\end{array}$ & $\begin{array}{c}0.292^{* * *} \\
(0.0774)\end{array}$ & $\begin{array}{l}0.162 * * \\
(0.0813)\end{array}$ \\
\hline married & & & $\begin{array}{c}59.94 * * * \\
(4.700)\end{array}$ & $\begin{array}{c}63.63^{* * *} \\
(5.724)\end{array}$ & $\begin{array}{c}56.80 * * * \\
(4.668)\end{array}$ & $\begin{array}{c}55.79 * * * \\
(5.646)\end{array}$ \\
\hline famsize & & & $\begin{array}{c}-7.414^{* * *} \\
(1.489)\end{array}$ & $\begin{array}{c}6.005^{* * *} \\
(1.697)\end{array}$ & $\begin{array}{c}-6.968 * * * \\
(1.477)\end{array}$ & $\begin{array}{c}5.333^{* * *} \\
(1.663)\end{array}$ \\
\hline large_firm & & & $\begin{array}{c}72.93 * * * \\
(6.032)\end{array}$ & $\begin{array}{c}46.94 * * * \\
(6.053)\end{array}$ & $\begin{array}{c}65.83^{* * *} \\
(6.040)\end{array}$ & $\begin{array}{c}34.00 * * * \\
(6.118)\end{array}$ \\
\hline In_hrp1 & & & $\begin{array}{c}52.20 * * * \\
(3.738)\end{array}$ & $\begin{array}{c}66.46^{* * *} \\
(3.795)\end{array}$ & $\begin{array}{c}49.43 * * * \\
(3.737)\end{array}$ & $\begin{array}{c}71.36 * * * \\
(3.867)\end{array}$ \\
\hline daily_hrs_j1 & & & $\begin{array}{c}0.406 * * \\
(0.198)\end{array}$ & $\begin{array}{c}0.597^{* * *} \\
(0.176)\end{array}$ & $\begin{array}{c}0.193 \\
(0.197)\end{array}$ & $\begin{array}{c}0.557^{* * *} \\
(0.174)\end{array}$ \\
\hline Constant & $\begin{array}{c}155.9 * * * \\
(3.523)\end{array}$ & $\begin{array}{c}196.1 * * * \\
(4.314)\end{array}$ & $\begin{array}{l}-43.20 \\
(122.8)\end{array}$ & $\begin{array}{l}-129.8 \\
(128.0)\end{array}$ & $\begin{array}{c}102.1 \\
(124.2)\end{array}$ & $\begin{array}{l}-121.9 \\
(129.2)\end{array}$ \\
\hline $\begin{array}{l}\text { Regional Controls } \\
\text { Industry Controls } \\
\text { Occupation Controls }\end{array}$ & $\begin{array}{l}\text { No } \\
\text { No } \\
\text { No }\end{array}$ & $\begin{array}{l}\text { No } \\
\text { No } \\
\text { No }\end{array}$ & $\begin{array}{l}\text { Yes } \\
\text { No } \\
\text { No }\end{array}$ & $\begin{array}{l}\text { Yes } \\
\text { No } \\
\text { No }\end{array}$ & $\begin{array}{l}\text { Yes } \\
\text { Yes } \\
\text { Yes }\end{array}$ & $\begin{array}{l}\text { Yes } \\
\text { Yes } \\
\text { Yes }\end{array}$ \\
\hline $\begin{array}{l}\text { Observations } \\
\text { R-squared }\end{array}$ & $\begin{array}{c}21,780 \\
0.106 \\
\end{array}$ & $\begin{array}{c}21,776 \\
0.091 \\
\end{array}$ & $\begin{array}{c}21,780 \\
0.194 \\
\end{array}$ & $\begin{array}{c}21,776 \\
0.202 \\
\end{array}$ & $\begin{array}{c}21,780 \\
0.209 \\
\end{array}$ & $\begin{array}{c}21,776 \\
0.231 \\
\end{array}$ \\
\hline
\end{tabular}


Difference-in-Difference Estimation Results (Models 3a and 3b)

\begin{tabular}{|c|c|c|c|c|c|c|c|}
\hline \multicolumn{8}{|c|}{ Robust standard errors in parentheses. ${ }^{* * *} p<0.01,{ }^{* *} p<0.05,{ }^{*} p<0.1$} \\
\hline \multicolumn{4}{|c|}{$\begin{array}{l}\text { Logistic Estimation -- Marginal Effects } \\
\qquad \text { (model 3a) }\end{array}$} & \multicolumn{4}{|c|}{$\begin{array}{l}\text { OLS Estimation -- Coefficients } \\
\text { (model } 3 b)\end{array}$} \\
\hline VARIABLES & \begin{tabular}{|c} 
Voluntary \\
Employer \\
Switch
\end{tabular} & $\begin{array}{l}\text { Voluntary } \\
\text { Employer } \\
\text { Switch }\end{array}$ & $\begin{array}{c}\text { Voluntary } \\
\text { Employer } \\
\text { Switch }\end{array}$ & VARIABLES & $\begin{array}{c}\text { Tenure at } \\
\text { Primary } \\
\text { Employer (In } \\
\text { Weeks) }\end{array}$ & $\begin{array}{c}\text { Tenure at } \\
\text { Primary } \\
\text { Employer (In } \\
\text { Weeks) }\end{array}$ & $\begin{array}{c}\text { Tenure at } \\
\text { Primary } \\
\text { Employer (In } \\
\text { Weeks) }\end{array}$ \\
\hline R_ESHI & $\begin{array}{l}-0.00303 \\
(0.00656)\end{array}$ & $\begin{array}{c}-0.0266^{* *} \\
(0.0103)\end{array}$ & $\begin{array}{c}-0.0249 * * \\
(0.0102)\end{array}$ & R_ESHI & $\begin{array}{c}19.60 \\
(15.47)\end{array}$ & $\begin{array}{c}54.74^{* * *} \\
(18.55)\end{array}$ & $\begin{array}{r}42.35^{* *} \\
(18.69)\end{array}$ \\
\hline P_ESHi & & $\begin{array}{l}-0.0112^{*} \\
(0.00574)\end{array}$ & $\begin{array}{l}-0.0102^{*} \\
(0.00577)\end{array}$ & P_ESHi & & $\begin{array}{l}-11.63 \\
(16.67)\end{array}$ & $\begin{array}{l}-17.08 \\
(16.76)\end{array}$ \\
\hline R_ESHI*P_ESHI & & $\begin{array}{c}0.0565^{* * *} \\
(0.0139)\end{array}$ & $\begin{array}{c}0.0528^{* * *} \\
(0.0137)\end{array}$ & R_ESHI*P_ESHI & & $\begin{array}{c}-83.75^{* * * *} \\
(18.82)\end{array}$ & $\begin{array}{c}-70.27^{* * *} \\
(18.93)\end{array}$ \\
\hline life $\_1$ & $\begin{array}{l}-0.0121^{*} \\
(0.00695)\end{array}$ & $\begin{array}{l}-0.0113^{*} \\
(0.00667)\end{array}$ & $\begin{array}{l}-0.0108^{*} \\
(0.00653)\end{array}$ & life _1 & $\begin{array}{c}3.071 \\
(13.14)\end{array}$ & $\begin{array}{c}0.384 \\
(13.11)\end{array}$ & $\begin{array}{l}-7.265 \\
(13.04)\end{array}$ \\
\hline mat_pat_j1 & $\begin{array}{c}-0.0246 * * * \\
(0.00670)\end{array}$ & $\begin{array}{c}-0.0230 * * * \\
(0.00649)\end{array}$ & $\begin{array}{c}-0.0234 * * * \\
(0.00646)\end{array}$ & mat_pat_j1 & $\begin{array}{c}43.10^{* * * *} \\
(12.01)\end{array}$ & $\begin{array}{c}39.63 * * * \\
(11.99)\end{array}$ & $\begin{array}{c}36.12^{* * *} \\
(11.81)\end{array}$ \\
\hline retire_j1 & $\begin{array}{l}-0.0215 * * * \\
(0.00653)\end{array}$ & $\begin{array}{l}-0.0201 * * * \\
(0.00632)\end{array}$ & $\begin{array}{l}-0.0186 * * * \\
(0.00621)\end{array}$ & retire $j 1$ & $\begin{array}{l}79.72 * * * \\
(12.13)\end{array}$ & $\begin{array}{c}78.28 * * * \\
(12.06)\end{array}$ & $\begin{array}{c}68.90 * * * \\
(12.02)\end{array}$ \\
\hline union & $\begin{array}{l}0.000350 \\
(0.00567)\end{array}$ & $\begin{array}{c}0.00239 \\
(0.00566)\end{array}$ & $\begin{array}{c}0.00506 \\
(0.00604)\end{array}$ & union & $\begin{array}{c}163.3^{* * *} \\
(10.79)\end{array}$ & $\begin{array}{c}156.9 * * * \\
(10.81)\end{array}$ & $\begin{array}{c}147.4^{* * * *} \\
(11.29)\end{array}$ \\
\hline married & $\begin{array}{l}-0.0109 * * \\
(0.00494)\end{array}$ & $\begin{array}{c}-0.0169 * * * \\
(0.00554)\end{array}$ & $\begin{array}{c}-0.0162 * * * \\
(0.00546)\end{array}$ & minority & $\begin{array}{c}-18.23 * * \\
(8.308)\end{array}$ & $\begin{array}{c}-18.48^{* *} \\
(8.290)\end{array}$ & $\begin{array}{c}-17.24 * * \\
(8.264)\end{array}$ \\
\hline famsize & $\begin{array}{l}-0.00143 \\
(0.00157)\end{array}$ & $\begin{array}{l}-0.00143 \\
(0.00154)\end{array}$ & $\begin{array}{l}-0.00121 \\
(0.00150)\end{array}$ & highest_grade & $\begin{array}{c}-12.48^{* * * *} \\
(1.679)\end{array}$ & $\begin{array}{c}-12.08^{* * * *} \\
(1.672)\end{array}$ & $\begin{array}{c}-14.07 * * * \\
(1.834)\end{array}$ \\
\hline minority & $\begin{array}{l}-0.00285 \\
(0.00402)\end{array}$ & $\begin{array}{l}-0.00275 \\
(0.00387)\end{array}$ & $\begin{array}{l}-0.00239 \\
(0.00387)\end{array}$ & ageatint & $\begin{array}{c}21.96 \\
(22.73)\end{array}$ & $\begin{array}{c}2.247 \\
(22.72)\end{array}$ & $\begin{array}{l}-25.94 \\
(23.99)\end{array}$ \\
\hline highest_grade & $\begin{array}{l}-0.000177 \\
(0.000820)\end{array}$ & $\begin{array}{l}-0.000206 \\
(0.000798)\end{array}$ & $\begin{array}{c}0.000386 \\
(0.000903)\end{array}$ & ageatint_2 & $\begin{array}{c}-0.00604 \\
(0.252)\end{array}$ & $\begin{array}{c}0.182 \\
(0.252)\end{array}$ & $\begin{array}{l}0.477^{*} \\
(0.263)\end{array}$ \\
\hline ageatint & $\begin{array}{c}-0.0383^{* * *} \\
(0.0102)\end{array}$ & $\begin{array}{c}-0.0333^{* * *} \\
(0.00990)\end{array}$ & $\begin{array}{c}-0.0296 * * * \\
(0.0105)\end{array}$ & male & $\begin{array}{c}0.566 \\
(8.316)\end{array}$ & $\begin{array}{l}-11.56 \\
(8.466)\end{array}$ & $\begin{array}{c}0.00846 \\
(9.354)\end{array}$ \\
\hline ageatint_2 & $\begin{array}{c}0.000388^{* * *} \\
(0.000113)\end{array}$ & $\begin{array}{c}0.000341^{* * *} \\
(0.000110)\end{array}$ & $\begin{array}{c}0.000305^{* * *} \\
(0.000115)\end{array}$ & married & $\begin{array}{c}61.69 * * * \\
(9.395)\end{array}$ & $\begin{array}{c}87.20 * * * \\
(10.15)\end{array}$ & $\begin{array}{c}80.45^{* * *} \\
(10.09)\end{array}$ \\
\hline male & $\begin{array}{c}-0.0117 * * * \\
(0.00394)\end{array}$ & $\begin{array}{c}-0.00926 * * \\
(0.00382)\end{array}$ & $\begin{array}{r}-0.0105 * * \\
(0.00442)\end{array}$ & famsize & $\begin{array}{l}-4.197 \\
(3.046)\end{array}$ & $\begin{array}{l}-4.220 \\
(3.040)\end{array}$ & $\begin{array}{l}-4.840 \\
(2.999)\end{array}$ \\
\hline large_firm & $\begin{array}{c}0.00169 \\
(0.00593)\end{array}$ & $\begin{array}{c}0.00296 \\
(0.00584)\end{array}$ & $\begin{array}{c}0.00349 \\
(0.00588)\end{array}$ & large_firm & $\begin{array}{c}85.04 * * * \\
(10.75)\end{array}$ & $\begin{array}{c}81.84 * * * \\
(10.76)\end{array}$ & $\begin{array}{c}70.27 * * * \\
(10.79)\end{array}$ \\
\hline In_hrp1 & $\begin{array}{c}-0.0148 * * * \\
(0.00199)\end{array}$ & $\begin{array}{c}-0.0132^{* * * *} \\
(0.00189)\end{array}$ & $\begin{array}{c}-0.0137 * * * \\
(0.00204)\end{array}$ & In_hrp1 & $\begin{array}{c}100.5^{* * * *} \\
(6.832)\end{array}$ & $\begin{array}{c}96.18^{* * * *} \\
(6.841)\end{array}$ & $\begin{array}{c}97.22 * * * \\
(6.987)\end{array}$ \\
\hline daily_hrs_j1 & $\begin{array}{c}0.00169 * \\
(0.000982)\end{array}$ & $\begin{array}{c}0.00175^{*} \\
(0.000937)\end{array}$ & $\begin{array}{c}0.00173^{*} \\
(0.000925)\end{array}$ & $\begin{array}{c}\text { daily_hrs_j1 } \\
\text { Constant }\end{array}$ & $\begin{array}{c}1.686 \\
(2.256) \\
-821.4 \\
(510.6)\end{array}$ & $\begin{array}{c}0.922 \\
(2.273) \\
-308.6 \\
(510.5)\end{array}$ & $\begin{array}{c}0.478 \\
(2.255) \\
477.3 \\
(549.3)\end{array}$ \\
\hline Regional Controls & Yes & Yes & Yes & Regional Controls & Yes & Yes & Yes \\
\hline Industry Controls & No & No & Yes & Industry Controls & No & No & Yes \\
\hline Occupation Controls & No & No & Yes & Occupation Controls & No & No & Yes \\
\hline Observations & 10,354 & 10,354 & 10,304 & Observations & 10,354 & 10,354 & 10,354 \\
\hline Log Likelihood & -2050.11 & -2030.47 & -2014.24 & R-squared & 0.160 & 0.166 & 0.187 \\
\hline
\end{tabular}




\section{Appendix B: Imputing Voluntary Job Switches}

Survey respondents were asked in each round whether they left their last primary job for one of the following reasons. Each reason was coded either as a voluntary switch, or as an involuntary switch. Some of the reasons are not obviously voluntary or involuntary, such as "End of Temporary or Seasonal Job." Running several sensitivity analyses revealed that coding these variables one way or the other does not substantially alter our estimated results. The following table lists all of the possible responses for a voluntary job switch in survey rounds after the year 2002. The table for answers before 2002 is included later.

\begin{tabular}{|c|c|}
\hline Reason & Coding \\
\hline Layoff, Job Eliminated & Involuntary \\
\hline Company, Office or Workplace Closed & Involuntary \\
\hline End of Temporary or Seasonal Job & Voluntary \\
\hline Discharged or Fired & Involuntary \\
\hline Government Program Ended & Involuntary \\
\hline Quit for Pregnancy, Childbirth or Adoption & Voluntary \\
\hline Quit to Look for Another Job & Voluntary \\
\hline Quit to Take Another Job & Voluntary \\
\hline Quit for other reasons & Voluntary \\
\hline Quit because of R's ill health, disability or medical problems & Voluntary \\
\hline Moved to another geographic area & Voluntary \\
\hline $\begin{array}{l}\text { Quit to spend time with or take care of family/spouse/parents or other } \\
\text { family members }\end{array}$ & Voluntary \\
\hline Quit because didn't like job pay or benefits & Voluntary \\
\hline Quit to attend school or training & Voluntary \\
\hline Went to jail or prison, had legal problems & Involuntary \\
\hline Transportation problems & Voluntary \\
\hline Retired & Voluntary \\
\hline No desirable assignments & Voluntary \\
\hline Job assigned through temp agency or contract firm became permanent & Voluntary \\
\hline Dissatisfied with job-matching service & Voluntary \\
\hline Project completed or job ended & Involuntary \\
\hline
\end{tabular}


Below is the coding for voluntary switches before 2002. There are fewer categories, but I attempted to make them as consistent as possible with the coding of categories after 2002. The category “Quit for Other Reasons (SPECIFY)” was difficult to categorize, but quitting implies some level of personal volition, therefore I code it as a voluntary job switch.

\begin{tabular}{|ll|}
\hline Layoff & Involuntary \\
\hline Plant Closed & Involuntary \\
\hline End of Temporary or Seasonal Job & Voluntary \\
\hline Discharged or Fired & Involuntary \\
\hline Program Ended & Involuntary \\
\hline $\begin{array}{l}\text { Quit for Pregnancy or Family-Related } \\
\text { Reasons }\end{array}$ & Voluntary \\
\hline Quit to Look for Another Job & Voluntary \\
\hline Quit for Other Reasons (SPECIFY) & Voluntary \\
\hline
\end{tabular}




\section{Appendix C: Descriptive Statistics for Difference-in-Difference Estimates}

\section{Descriptive Statistics}

For models $\mathbf{3 a}$ and $\mathbf{3 b}$

\begin{tabular}{lrrrrr} 
Variable & Obs & Mean & Std. Dev. & Min & Max \\
\hline \hline v_switch_v3 & 10354 & 0.0564033 & 0.2307101 & 0 & 1 \\
Tenure & 10354 & 485.0022 & 420.3336 & 1 & 1969 \\
R_ESHI & 10354 & 0.845084 & 0.361842 & 0 & 1 \\
P_ESHI & 10354 & 0.2875217 & 0.4526287 & 0 & 1 \\
R_ESHIxP_E I & 10354 & 0.2030133 & 0.4022618 & 0 & 1 \\
life_j1 & 10354 & 0.751497 & 0.4321658 & 0 & 1 \\
mat_pat_11 & 10354 & 0.7696542 & 0.4210745 & 0 & 1 \\
retire_j1 & 10354 & 0.783079 & 0.4121683 & 0 & 1 \\
union & 10354 & 0.1817655 & 0.3856698 & 0 & 1 \\
married & 10354 & 0.6696929 & 0.4703464 & 0 & 1 \\
famsize & 10354 & 3.072339 & 1.434181 & 1 & 12 \\
minority & 10354 & 0.4538343 & 0.4978882 & 0 & 1 \\
highest_gr e & 10354 & 13.70195 & 2.455599 & 0 & 20 \\
ageatint & 10354 & 46.35329 & 3.295628 & 37 & 53 \\
ageatint_2 & 10354 & 2159.488 & 301.5069 & 1369 & 2809 \\
male & 10354 & 0.4394437 & 0.4963434 & 0 & 1 \\
n_central & 10354 & 0.2451227 & 0.4301807 & 0 & 1 \\
south & 10354 & 0.4101796 & 0.4918899 & 0 & 1 \\
west & 10354 & 0.1881398 & 0.3908427 & 0 & 1 \\
large_firm & 10354 & 0.1836005 & 0.3871768 & 0 & 1 \\
In_hrp1 & 10354 & 2.879144 & 0.7240602 & -4.60517 & 6.682196 \\
daily_hrs_1 & 10354 & 8.351652 & 1.726735 & 1 & 24
\end{tabular}


Appendix D: Definitions of variables

\begin{tabular}{|c|c|c|}
\hline \multicolumn{2}{|r|}{ Definition } & \multirow{2}{*}{$\begin{array}{l}\text { Values } \\
1 \text { 1==yes, } 0==\text { no }\end{array}$} \\
\hline R_ESHI & $\begin{array}{l}\text { Did respondent's employer pay for any of his/her } \\
\text { health insurance costs? }\end{array}$ & \\
\hline Voluntary_Switch & Did respondent voluntarily switch jobs? & $1==$ yes, $0==$ no \\
\hline Tenure & $\begin{array}{l}\text { How many weeks has the respondent worked on } \\
\text { his/her primary job? }\end{array}$ & \# of weeks \\
\hline P_ESHI & $\begin{array}{l}\text { Did the partner/spouse of the respondent pay for } \\
\text { any of the respondent's health insurance costs? }\end{array}$ & $1==$ yes, $0==$ no \\
\hline R_ESHI*P_ESHI & $\begin{array}{l}\text { Interaction term for R_ESHI*P_ESHI. Was part of } \\
\text { the respondent's health insurance paid by both } \\
\text { the respondent's employer and that of his/her } \\
\text { spouse? }\end{array}$ & $1==y e s, 0==$ no \\
\hline life_j1 & $\begin{array}{l}\text { Was respondent offered life insurance by his/her } \\
\text { employer? }\end{array}$ & $1==$ yes, $0==$ no \\
\hline mat_pat_j1 & $\begin{array}{l}\text { Was respondent offered maternity/paternity } \\
\text { benefits by his/her employer? }\end{array}$ & $1==y e s, 0==$ no \\
\hline retire_j1 & $\begin{array}{l}\text { Was respondent offered retirement benefits by } \\
\text { his/her employer? }\end{array}$ & $1==y e s, 0==$ no \\
\hline union & $\begin{array}{l}\text { Is respondent part of a union or similar } \\
\text { association on primary job? }\end{array}$ & $1==$ yes, $0==$ no \\
\hline minority & Is the respondent African American or Hispanic? & $1==y e s, 0==$ no \\
\hline highest_grade & $\begin{array}{l}\text { What was the highest grade completed by the } \\
\text { respondent as of May 1st of the survey year }\end{array}$ & $1==$ yes, $0==$ no \\
\hline ageatint & $\begin{array}{l}\text { What is the age of the respondent at the time of } \\
\text { the interview? }\end{array}$ & \# of years \\
\hline ageatint_2 & Age of respondent at interview squared & (age at interview)^2 \\
\hline married & Is the respondent married? & $1==$ yes, $0==$ no \\
\hline famsize & What is the size of the respondent's family? & \# of family members \\
\hline northeast & $\begin{array}{l}\text { Is the respondent currently residing in the } \\
\text { northeast? }\end{array}$ & $1==y e s, 0==$ no \\
\hline n_central & $\begin{array}{l}\text { Is the respondent currently residing in the north- } \\
\text { central region? }\end{array}$ & $1==y e s, 0==$ no \\
\hline south & Is the respondent currently residing in the south? & $1==$ yes, $0==$ no \\
\hline west & Is the respondent currently residing in the west? & $1==y e s, 0==$ no \\
\hline large_firm & $\begin{array}{l}\text { Does the respondent's firm have more than } 500 \\
\text { employees at the respondent's location? }\end{array}$ & $1==$ yes, $0==$ no \\
\hline In_hrp1 & Log of the employer's hourly rate of pay & $\ln$ (wage) \\
\hline daily_hrs_j1 & $\begin{array}{l}\text { How many hours does the respondent usually } \\
\text { work on his/her primary job each day? }\end{array}$ & \# of hours \\
\hline
\end{tabular}

